\title{
PLURALISME HUKUM SEBAGAI STRATEGI PEMBANGUNAN HUKUM PROGRESIF DI BIDANG AGRARIA DI INDONESIA Widhiana H Puri*
}

\begin{abstract}
Abstrack: Pluralism of agrarian law is a consequence of the choice of society law that has a diversity of culture, ethnicity, customs and religion. This condition creates the selection to use legal norms beside national laws defined by the state. The philosophy is to find and to aceuire the most appropriate legal order and provide justice for the people. This concept consistent with the progressive nature of the law that led to a dynamic legal system and was processed following the dynamics of the community responsive to the needs and aspirations of justice in society. By using non state law as a complement of the state law, the chance of the state to euickly respons every dynamics of the community is possible, making the law progressive and responsive. This paper is a normative article with descriptive analytic from the perspective of philosophy of jurisprudence.
\end{abstract}

Keywords: Pluralism agrarian law, progressive law, justice

Intisari: Pluralisme hukum agraria adalah sebuah kondisi yang menjadi konsekuensi atas pilihan hukum masyarakat yang memiliki keragaman budaya, suku, adat istiadat serta agama. Kondisi ini menciptakan adanya pilihan norma hukum yang digunakan selain hukum nasional yang ditetapkan negara. Filosofinya adalah menemukan dan memperoleh tatanan hukum yang paling sesuai dan memberikan keadilan bagi masyarakat. Konsep ini sejalan dengan hakikat hukum progresif yang mengarah pada sebuah sistem hukum yang dinamis dan berproses mengikuti dinamika masyarakat sehingga responsif terhadap kebutuhan dan cita keadilan dalam masyarakat. Dengan menempatkan hukum masyarakat sebagai pelengkap hukum negara, maka peluang negara untuk merespon setiap dinamika dalam masyarakat secara cepat dapat dilakukan sehingga terwujud hukum progresif dan responsif. Kajian ini bersifat normatif dengan pendekatan deskriptif analitis dari perspektif filsafat ilmu hukum.

Kata Kunci: Pluralisme hukum agraria, hukum progresif, dan keadilan.

\section{A. Pendahuluan}

Perekonomian Indonesia berdasar atas demokrasi ekonomi dan kemakmuran bagi semua orang. Rumusan penjelasan Undang-undang Dasar Tahun 1945 (selanjutnya disebut UUD 1945) ini telah disadari oleh para pendiri bangsa, yang menempatkan tanah sebagai unsur penting serta harus dikuasai oleh negara sebagaimana pendapat Yance Arizona:

"Tanah, sebagai faktor produksi yang utama dalam masyarakat Indonesia haruslah di bawah kekuasaan negara. Tanah tidak boleh menjadi alat kekuasaan or-

\footnotetext{
* Kandidat Doktor Fakultas Hukum, Universitas Gadjah Mada, Staf Pengajar Sekolah Tinggi Pertanahan Yogyakarta. Email: widhianapuri@yahoo.com.
}

ang seorang untuk menindas dan memeras hidup orang lain." (Yance Arizona 2014, 32).

Memperhatikan rumusan di atas, esensi kesejahteraan masyarakat melalui pemerataan/ keadilan khususnya dalam bidang ekonomi melalui distribusi pengelolaan sumber daya alam (tanah) yang baik akan sangat berpengaruh terhadap kesejahteraan masyarakat. Hal ini menjadi kewenangan negara sebagaimana diamanatkan oleh ketentuan Pasal 33 UUD 1945.

Kehidupan bernegara di Indonesia berdasarkan pada hukum. Segala sendi kehidupan diatur, dikontrol dan dibentuk berdasarkan norma dan kaidah yang bertujuan untuk menciptakan ketertiban dan keadilan bagi semua anggota masyarakat. Sebagaimana pendapat Philippe Nonet 
dan Philippe Selznick bahwa tipe hukum di dunia dapat dibedakan menjadi 3 macam, yakni hukum represif, hukum otonom, dan hukum responsif (Philippe Nonet dan Philip Selznick 2003, 8). Sementara itu Satjipto Raharjo memperkenalkan keberadaan hukum progresif sebagai sebuah tipe hukum yang berkarakter responsif yang sematamata bertujuan untuk merespon keinginan/cita hukum masyarakat dan bukan hanya menjadi sarana represif dari penguasa. Keberadaan hukum progresif ini disebut merupakan hukum yang paling baik yang akan mampu memberikan keadilan bagi masyarakat karena sesuai dengan kebutuhan masyarakat yang dinamis. Semua elemen pembentuk hukum baik norma, penegak hukum, dan masyarakat sebagaimana persoalan struktur, substansi, dan kultur hukum harus bersinergi dalam melaksanakannya.

Kehidupan hukum dalam negara yang kaya akan kemajemukan masyarakat menunjukkan gejala pluralisme. Hal ini menjadi langkah dan strategi masyarakat dalam merespons pengaturan hukum negara yang cenderung kaku dan statis. Tujuannya semata sebagai upaya memenuhi cita hukum masyarakat sebagaimana pendapat Gustav Radburch yang membaginya atas kepastian, keadilan, dan kemanfaatan. Hal ini lah yang menjadi harapan ideal tentang hukum bagi masyarakat.

Berpijak dari latar belakang di atas, penulis tertarik untuk mengupas secara lebih mendetail dari kajian filsafat ilmu hukum secara deskriptif dalam tataran normatif. Sebagai sebuah filsafat keilmuan, kehadiran postulat/proposisi menjadi pijakan awal untuk melakukan verifikasi dan konfirmasi atas berbagai komponen yang melingkupinya dengan analisis berbagai aspek baik teleologi, ontologi, epistimologi dan aksiologinya. Postulat/proposisi awal tulisan ini didasarkan pada asumsi bahwa kondisi pluralisme hukum agraria berpotensi melahirkan hukum agraria yang progresif untuk mewujudkan keadilan bagi masyarakat Indonesia. Berdasarkan hal tersebut, permasalahan utama yang ingin dibahas adalah bagaimana pluralisme hukum agraria dapat melahirkan hukum yang progresif bagi masyarakat?

\section{B. Karakter Hukum Progresif di Negara Demokratis}

Negara Indonesia adalah negara yang demokratis. Slogan ini semakin sering kita dengar manakala kita menginjakkan kaki di alam reformasi Indonesia. Menurut Kamus Besar Bahasa Indonesia, demokrasi adalah (bentuk atau sistem) pemerintahan yang seluruh rakyatnya turut serta memerintah dengan perantaraan wakilnya; pemerintahan rakyat; gagasan atau pandangan hidup yang mengutamakan persamaan hak dan kewajiban serta perlakuan yang sama bagi semua warga negara. Sedangkan demokratis berarti bersifat demokrasi; berciri demokrasi. Demokrasi memberikan pancaran legitimasi pada kehidupan modern: hukum, undang-undang, dan politik kelihatan absah ketika semua itu bersifat "demokratis" (David Held 2004, 3-4). Segala klaim kepentingan kaum marjinal dan pilihan-pilihan politik seolah hanya dapat diorganisasikan, diartikulasikan, dan dinegosiasikan dalam demokrasi. Tentunya hal ini tidak sepenuhnya benar, karena demokrasi faktanya memiliki sisi lain yang sangat ditakuti oleh pemerintah negara karena merupakan sebuah sistem yang tidak stabil sehingga sangat sulit dibangun dan dipertahankan eksistensinya.

Berbicara tentang hukum yang demokratis sangat berkaitan erat dengan sistem politik yang digunakan oleh negara. Politik dan hukum laksana dua sisi mata uang yang saling berpengaruh dan mempengaruhi. Mahfud dalam bukunya Politik Hukum di Indonesia menjelaskan terdapat keterkaitan yang sangat erat antara hukum dan politik. Mochtar Kusumaatmadja dalam Mahfud menyatakan bahwa politik dan hukum itu interdeterminan, sebab politik tanpa hukum itu zalim, sedangkan hukum tanpa politik itu lumpuh (Moh. Mahfud 2011, 5). Soal apa yang menjadi produk 
apa, itupun sangat relatif. Hukum sebagai produk politik benar jika didasarkan pada das sein dengan mengonsepkan hukum sebagai undang-undang. Namun jika hukum sebagai dasar mencari kebenaran ilmiah dan memberi arti hukum di luar undang-undang, maka politik merupakan produk hukum.

Tabel 1. Indikator Kondisi Sistem Politik dan Karakter Produk Hukum

Indikator Sistem Politik

\begin{tabular}{|c|c|}
\hline Konfigurasi Politik Demokratis & Konfigurasi Politik Otoriter \\
\hline $\begin{array}{l}\text { 1. Parpol dan parlemen kuat, } \\
\text { menentukan haluan atau } \\
\text { kebijakan negara }\end{array}$ & $\begin{array}{l}\text { 1. Parpol dan parlemen lemah, di } \\
\text { bawah kendali eksekutif }\end{array}$ \\
\hline $\begin{array}{l}\text { 2. Lembaga eksekutif } \\
\text { (pemerintah netral) }\end{array}$ & $\begin{array}{l}\text { 2. Lembaga eksekutif } \\
\text { (pemerintah) intervensionis }\end{array}$ \\
\hline $\begin{array}{l}\text { 3. Pers bebas, tanpa sensor dan } \\
\text { pemberedelan }\end{array}$ & $\begin{array}{l}\text { 3. Pers terpasung, diancam sensor } \\
\text { dan pemberedelan }\end{array}$ \\
\hline
\end{tabular}

Indikator Karakter Produk Hukum

\begin{tabular}{|c|c|}
\hline Konfigurasi Politik Demokratis & Konfigurasi Politik Otoriter \\
\hline $\begin{array}{l}\text { 1. Parpol dan parlemen kuat, menentukan } \\
\text { haluan atau kebijakan negara }\end{array}$ & $\begin{array}{l}\text { 1. Parpol dan parlemen lemah, di } \\
\text { bawah kendali eksekutif }\end{array}$ \\
\hline 2. Lembaga eksekutif (pemerintah netral) & $\begin{array}{l}\text { 2. Lembaga eksekutif (pemerintah) } \\
\text { intervensionis }\end{array}$ \\
\hline $\begin{array}{l}\text { 3. Pers bebas, tanpa sensor dan } \\
\text { pemberedelan }\end{array}$ & $\begin{array}{l}\text { 3. Pers terpasung, diancam sensor dan } \\
\text { pemberedelan }\end{array}$ \\
\hline
\end{tabular}

Sumber: Moh. Mahfud 20II, 7.

Penekanannya dalam hal ini bahwa hubungan kausalitas tersebut benar selama menyangkut hukum publik yang berkaitan dengan gezagsverhouding (hubungan kekuasaan). Artinya untuk hukum publik yang berhubungan dengan kekuasaan konfigurasi politik yang demokratis melahirkan hukum yang berwatak responsif, sedangkan konf igurasi politik yang otoriter melahirkan hukum yang ortodoks.

Negara Indonesia menyatakan secara tegas sebagai negara yang berdasarkan demokrasi yaitu Pancasila. Berbagai literatur menunjukkan adanya perbedaan antara demokrasi normatif dan demokrasi empiris. Appearance suatu sistem politik dapat saja kelihatan demokrasi tetapi essence-nya sebenarnya otoriter. Di sini demokrasi tidak diartikan sebagai pemerintahan yang dari, oleh, dan untuk rakyat, melainkan hanya sekedar pemerintahan untuk rakyat sehingga rakyat sekedar menikmati hasil atau kemanfaatannya. Demokrasi yang sesungguhnya adalah sistem politik yang secara normatif dan empiris atau secara appearance dan essence, membuka peluang luas bagi berperannya rakyat untuk aktif menentukan kebijaksanaan negara dan jalannya pemerintahan (Moh. Mahfud 2011, 11). Indikator konfigurasi politik adalah peranan lembaga perwakilan rakyat, pers, dan eksekutif sedangkan indikator bagi produk hukumnya adalah proses pembuatannya, pemberian fungsi, dan peluang menafsirkannya. Proses pembuatannya bersifat partisipatif dalam arti menyerap partisipasi kelompok sosial maupun individu dalam masyarakat, menyerap aspirasi masyarakat secara besar sehingga mengkristalisasikan berbagai kehendak masyarakat yang saling bersaingan, dan membatasi space bagi pemerintah untuk membuat tafsiran-tafsiran (interpretasi) yang ditentukan kekuasaan politiknya sendiri. Dengan kata lain, demokrasi merupakan prasyarat untuk mampu menghasilkan produk hukum yang responsif sebagaimana hal yang disyaratkan dalam hukum progresif.

Partisipasi masyarakat dalam pembentukan peraturan perundang-undangan terkesan hanya formalitas belaka (Ahmad Yani 2013, 91). Keberadaan wakil rakyat di lembaga legislatif cenderung hanya mewakili kepentingan kelompok dan golongan tertentu. Akibatnya conflict of interest menjadi sangat menonjol dan diindikasikan juga melalui produk hukum yang dihasilkan yang sarat dengan kepentingan. Secara normatif ketentuan hukum telah mengatur mekanisme partisipasi masyarakat baik secara lisan maupun tertulis. Diantaranya melalui rapat dengat pendapat umum, kunjungan kerja, sosialisasi, dan/atau seminar, lokakarya dan/atau diskusi. Selain itu juga terdapat kemudahan masyarakat dalam memberikan masukan maupun mengakses informasi terkait dengan pembentukan perundang-undangan. Budi Winarno menyebutkan terdapat beberapa tahapan kebijakan publik diantaranya penyusunan agenda, formulasi kebijakan, adopsi kebijakan, implemen- 
tasi kebijakan, dan evaluasi kebijakan (Budi Winarno 2007, 33). Kesemuanya merupakan suatu rangkaian yang menuntut sistem pengawasan dan partisipasi masyarakat dalam sistem hukum yang demokratis. Namun pelaksanaan sangatlah sulit untuk melibatkan peran masyarakat dalam kegiatan tersebut, karena terbatasnya jalur politik yang memungkinkan masyarakat untuk dapat mengakses dan melakukan koreksi atas kebijakan dan hukum yang ada. Rendahnya partisipasi masyarakat mendorong hukum mencari jalan lain untuk menghasilkan tatanan yang lebih responsif melalui kondisi pluralisme hukum.

Istilah progresif menurut Kamus Besar Bahasa Indonesia berarti ke arah kemajuan; berhaluan ke arah perbaikan keadaan sekarang (tentang politik); bertingkat-tingkat naik (tentang aturan pemungutan pajak dan lain-lain). Istilah hukum progresif dikemukakan oleh Rahardjo menanggapi carut marutnya kondisi hukum di Indonesia. Menurut Satjipto Rahardjo dalam Sudjito, dimulai dari asumsi dasar bahwa hukum adalah institusi yang bertujuan mengantarkan manusia kepada kehidupan yang adil, sejahtera dan membuat manusia bahagia. Hukum dipandang sebagai sebuah proses yang terus menerus membangun dirinya menuju tataran yang ideal tersebut. Kualitas hukum sangat ditentukan oleh kemampuannya mengabdi kepada manusia dan kesempurnaan hukum dapat diverifikasi dalam faktor keadilan, kesejahteraan, dan kepedulian kepada rakyat. Pada hakikatnya "hukum selalu dalam proses menjadi" (law as a process, law in the making). Hukum bukan untuk hukum sendiri tetapi untuk kemanusiaan dan kemaslahatan umat (Sudjito 2013, 110). Secara sederhana hukum progresif ingin melakukan pembebasan, baik dalam cara berpikir maupun bertindak dalam hukum, sehingga mampu membiarkan hukum itu mengalir saja untuk menuntaskan tugasnya mengabdi kepada manusia dan kemanusiaan. Secara ontologi pun, jelas bahwa fokus kajian adalah pada pencapaian keadilan melalui hukum progresif. Pun demikian teleologi hukum progresif adalah untuk kemaslahatan manusia.

Upaya untuk membangun sebuah hukum agraria yang progresif disebut telah dilakukan pemerintah sejak berakhirnya kolonialisme melalui proklamasi kemerdekaan 17 Agustus 1945. Mahfud MD menyoroti perkembangan konfigurasi politik dengan produk hukum yang dihasilkan dalam 3 fase, yaitu demokrasi liberal (1945-1959), demokrasi terpimpin (1959-1966), dan era orde baru (19661998). Momen perubahan pemerintahan Indonesia yang ditandai dengan transisi dari masa kolonialisme Belanda menuju kemerdekaan pada fase demokrasi liberal merupakan saat yang tepat mewujudkan sebuah tatanan hukum baru yang sesuai kehendak masyarakat. Muncul berbagai tuntutan dalam pembentukan hukum agraria nasional. Terdapat 2 jalur langkah pembaruan hukum agraria yang dilakukan saat itu (Moh. Mahfud 2011, 120):

1. Pengundangan peraturan secara parsial

Beberapa peraturan tersebut antara lain: Penghapusan Hak Konversi dengan UU No. 13 Tahun 1948 Penghapusan Tanah Partikelir dengan UU No. 1 Tahun 1958, Perubahan Peraturan Persewaan Tanah Rakyat dengan UU Darurat No. 6 Tahun 1951, Penaikan Besarnya Canon dan Cijns dengan UU No. 78 Tahun 1957, Pengaturan Perjanjian Bagi Hasil dengan UU No. 2 Tahun 196o, dan lain-lain.

2. Panitia-panitia perancang UU Agraria

Kebijakan-kebijakan agraria tersebut menunjukkan politik pemerintah yang mengarah pada pembentukan produk hukum yang lebih baik dan sesuai dengan karakter masyarakat Indonesia. Motor utama penggerak kebijakan agraria di Indonesia adalah Undang-Undang Nomor 5 Tahun 1960 tentang Peraturan Dasar Pokok-pokok Agraria (UUPA) sebagai payung hukum dalam pengelolaan agraria di Indonesia. Norma hukum ini lahir sebagai upaya untuk membangun sistem hukum agraria nasional yang demokratis dan berorientasi 
pada kesejahteraan rakyat. Setelah berusia 32 tahun padaakhir tahun 1992, UUPAdinilai masih memiliki jiwa semangat yang tetap relevan dengan tuntutan perkembangan zaman, sebab masih dapat menampung dan menyelesaikan berbagai masalah kekinian yang muncul. Relevansi tersebut menurut Maria S.W. Sumardjono terkait erat dengan beberapa asas yang dimilikinya seperti asas fungsi sosial, asas landreform, dan asas perencanaan penggunaan tanah untuk kesejahteraan bersama (Moh. Mahfud 2011, 279-280). Kebijakan nyata yang lahir melalui UU ini adalah program landreform atau reforma agraria yang digadang-gadang bersifat responsif dan populis.

Contoh lain adalah penghapusan tanah partikelir sebagai sebuah kebijakan agraria yang ditetapkan pada tahun 1958, merupakan instrumen yang diwujudkan melalui penetapan UU No. 1 Tahun 1958 tentang Penghapusan Tanah Partikelir. Sebagai sebuah instrumen hukum yang lahir pada masa transisi, norma hukum ini merupakan sebuah gambaran hukum yang progresif yang dibentuk pemerintah sebagai produk politik yang diliputi nuansa demokrasi liberal. Karakter hukum yang dibangun didasarkan pada keinginan untuk mengakhiri sistem hukum kolonial yang menyengsarakan rakyat serta melakukan perombakan struktur penguasaan atas tanah atau yang lebih dikenal dengan reforma agraria. Sebagai sebuah hukum yang diharapkan responsif untuk mengakomodir berbagai kepentingan, instrumen hukum ini selayaknya menempatkan kesejahteraan rakyat yang tercermin melalui demokrasi ekonomi yang berkeadilan. Namun faktanya diperlukan perjuangan yang lebih sehingga instrumen hukum yang ada dapat efektif untuk mewujudkan cita-cita negara dan bangsa.

Sebagaimana telah disampaikan di awal, hukum progresif menjadi dambaan masyarakat. Untuk membangun sebuah hukum yang progresif, Satjipto Rahardjo mensyaratkan adanya proses hukum yang terus menerus membangun diri menuju progresi- vitas, yakni hukum mampu memberi kesejahteraan, keadilan, dan kepedulian pada manusia. Hukum bukanlah mengabdi bagi dirinya sendiri, melainkan untuk tujuan yang berada di luar dirinya. Secara umum, karakter hukum progresif diantaranya (Bernard L Tanya 2010, 214-216):

1. Hukum progresif menolak tradisi analytical jurisprudence atau rechtsdogmatiek yang cenderung bersifat otonom.

2. Hukum memiliki kepekaan pada persoalan yang timbul dari hubungan manusia, sehingga hukum harus emansipatoris (membebaskan) keterbelengguan manusia dalam strukturyang menindas baik politik, ekonomi, maupun sosial budaya.

3. Karakter hukum progresif menggunakan cara berfikir teleologis yang menganggap hukum sebagai hal yang penting namun bukan ukuran terakhir. Yang lebih penting adalah tujuan dan akibat.

4. Hukum progresif meletakkan diskresi sebagai hal yang penting dalam penyelenggaraan hukum. Hal ini karena penyelenggara hukum dituntut memilih dengan bijaksana bagaimana ia harus bertindak.

Atas dasar ini kemudian kita bisa melihatnya melalui perkembangan aliran pemikiran hukum yang sejalan diantaranya:

1. Sociological Jurisprudence dari Roscoe Pound yang memperkenalkan fungsi hukum sebagai "law as a tool of social engineering". Konsep ini sejalan dengan sifat progresivitas hukum yang terus dinamis menemukan esensi kebutuhan dan ideal masyarakat. Di sini fungsi hukum digunakan untuk mengarahkan masyarakat kepada keadaan baru yang lebih maju/baik.

2. Teori Hukum alam oleh Hans Kelsen tentang meta-yuridical. Bahwa esensi utama hukum adalah upaya the search for justice. Sehingga menempatkan keadilan sebagai hal yang utama dan tertinggi. Berdasarkan konsep atas pencapaian keadilan ini, mendorong mulculnya 
pilihan-pilihan hukum oleh masyarakat di luar hukum negara yang dirasa memberikan keadilan. Hal inilah yang kemudian mendorong kondisi pluralisme hukum khususnya dalam bidang agraria.

Menghadapi kondisi transisional yang dihadapi negara, dimana persoalan saling berhimpitan, serba darurat, dan penuh komplikasi, maka aparat penegak hukum dituntut melakukan langkahlangkah terobosan dalam menjalankan hukum tidak sekedar menerapkan peraturan secara hitam putih. Hal ini terutama saat berbagai ketentuan aturan hukum inkonsistensi, tumpang-tindih, bahkan disharmoni antara satu dengan yang lain. Sehingga diperlukan para pelaku hukum yang berani, visioner, dan kreatif. Termasuk juga saat egoisme sektoral muncul diantara lembaga-lembaga pemerintah yang memiliki kewenangan saling bersinggungan. Mereka harus mampu menemukan keadilan dan kebenaran diantara norma hukum yang ada dan berdasarkan logika moral yang baik. Namun yang menjadi kelemahan penganut positivisme hukum, seolah menafikan keberadaan sistem hukum lain di luar undang-undang yang secara de facto berkembang dan banyak digunakan oleh masyarakat. Kelemahan hukum nasional yang selalu terlambat dalam merespon dinamika masyarakat perlu di jawab dengan memunculkan pilihanpilihan hukum.

\section{Menimbang Rasa Keadilan di Bidang Agraria}

Lahirnya reformasi membawa perubahan mendasar dalam kebijakan pembangunan nasional di bidang ekonomi sebagaimana tertuang dalam Tap MPR X/MPR/1998 dan TAP MPR No. IX/MPR/ 2001 tentang Pembaharuan Agraria dan Pengelolaan Sumber Daya Alam. Ini dibuat atas dasar pertimbangan pelaksanaan demokrasi ekonomi sebagaimana amanat Pasal 33 ayat (3) UUD 1945. Disebutkan bahwa politik ekonomi mencakup kebijakan, strategi, dan pelaksanaan pembangunan ekonomi nasional sebagai perwujudan prinsipprinsip dasar demokrasi ekonomi yang mendahulukan kepentingan rakyat, dan dipergunakan untuk sebesar-besar kemakmuran rakyat.

Tanah sebagai basis usaha pertanian harus diutamakan penggunaan dan pemanfaatannya untuk pertumbuhan pertanian rakyatyang mampu melibatkan dan meningkatkan kemakmuran bagi pengusaha kecil, menengah maupun koperasi (Moh. Hatta 2005, 5). Disebutkan adanya tiga hal utama yang menentukan perekonomian suatu negeri, yaitu pertama, kekayaan tanahnya; kedua, kedudukannya terhadap negara lain dalam lingkungan internasional dan ketiga, sifat dan kecakapan rakyatnya. Faktor pertama sangat menentukan karena tanah bagi rakyat Indonesia bersifat sosio-magis. Hubungan manusia dengan tanah bersifat hakiki dan kedudukan tanah sangatlah penting baik sebagai faktor ekonomi dan sosial kemasyarakatan juga menjadi sarana hubungan religius dengan Tuhan. Sedangkan untuk Indonesia ada tambahan sebagai unsur keempat yaitu sejarah sebagai bekas negara jajahan (Moh. Hatta 2005, 55). Perekonomian Indonesia meliputi 3 hal, pertama, idiologi yaitu bagaimana mengadakan susunan ekonomi yang sesuai dengan cita-cita; kedua, soal politik perekonomian; ketiga, soal koordinasi bagaimana mengatur pembangunan perekonomian Indonesia agar sejalan dengan pembangunan dunia. Atas dasar ketiga hal tersebut kedudukan tanah baik sebagai faktor ekonomi maupun bernilai religius magis sangatlah sentral. Tanah sebagai bagian agraria haruslah diatur sedemikian rupa sehingga mampu memberikan kesejahteraan dan keadilan bagi seluruh rakyat. Pasal 2 Undang-undang No. 5 Tahun 1960 tentang Peraturan Dasar Pokok-pokok Agraria (UUPA) menentukan bagaimana negara dengan kewenangan yang diberikan kepadanya oleh bangsa Indonesia berwenang untuk mengatur dan mengelolanya bagi kesejahteraan rakyat. Artikulasi dari kewenangan ini kemudian melahirkan berbagai 
kebijakan dan perangkat ketentuan hukum yang ditetapkan negara dalam rangka mewujudkannya. Jika kita tarik kembali ke atas, penyelenggaraan pengelolaan negara khususnya dalam bidang agraria tentunya haruslah sesuai dengan falsafah bangsa Indonesia yang terurai dalam sila kelima Pancasila yakni keadilan sosial bagi seluruh rakyat Indonesia. Yaitu mewujudkan keadilan, kesejahteraan, dan kemanfaatannya bagi masyarakat luas.

Perspektif filsafat hukum mengajak pada alam pikiran untuk merenungi hakikat hukum dan nilai ideal yang diharapkan. Moral manusia haruslah menjadi dasar yang kuat dalam rangka formulasi bahkan sampai implementasi dan evaluasi aturan hukum. mencari hakikat keadilan tersebut yang faktanya tidak universal. Sudjito mengemukakan bahwa filsafat ilmu hukum adalah institusi pencarian jawaban atas persoalan-persoalan yang dihadapi manusia, mulai dari persoalan ketuhanan, alam semesta, sampai manusia itu sendiri (Sudjito Atmoredjo 2015, 9). Hubungan manusia dengan manusia yang ditata melalui norma dan hukum yang ada menjadi salah satu bidang garapan filsafat ilmu hukum yang arahnya adalah kemajuan/ progresivitas hidup.

Standar moral dan kemampuan logika akal untuk bisa melihat hakikat realitas keadilan dalam hukum dan ekonomi yang diharapkan masyarakat sifatnya materiil dan substantif. Bukan lagi tergantung pada prosedur dan formalitasyang ada, namun membutuhkan kontemplasi dan kebijaksanaan untuk dapat menemukannya. Ukuran keadilan seringkali ditafsirkan berbeda pun demikian keadilan itu berdimensi banyak dalam berbagai bidang misalnya ekonomi maupun hukum.

Kata keadilan berasal dari kata adil atau yang dalam bahasa Inggris disebut "justice", dan dalam bahasa Belanda "rechtvaardig". Adil artinya dapat diterima secara objektif. Sedangkan keadilan menunjukkan sifat (perbuatan, perlakuan) yang adil yang meliputi (Salim HS \& Erlies Septiana N 2014, 25):
1. Tidak berat sebelah atau tidak memihak;

2. Berpihak pada kebenaran;

3. Sepatutnya atau tidak sewenang-wenang.

Anton F Susanto menempatkan keadilan dibenturkan dengan keraguan dan ketidakadilan, bahwa sesungguhnya keadilan tidak akan berdaya tanpa ketidakadilan dan keraguan (Anton F Susanto 2010, 23). Menurut pendapatnya ketika keadilan dihadapkan pada hal-hal yang meragukan, dan tidak adil akan masuk dalam wilayah non sistematik bahkan hampir aphoristic, karena di bagian tersebut keadilan menjadi labil dan goyah. Sehingga keadilan (hukum) dianggap bersifat plural dan plastik (Erlyn Indarti 2008, 33).

Keadilan sebagai nilai sosial memiliki makna yang luas, bahkan pada suatu titik bisa bertentangan dengan hukum sebagai suatu tata nilai sosial (Inge Dwisvimiar 2011,522). Nilai keadilan atas masingmasing orang tentunya berbeda. Suatu nilai atas masyarakat tertentu mungkin baik dan benar, namun bagi masyarakat lain bisa jadi salah dan tidak adil. Sehingga memerlukan pemahaman dan perenungan yang mendalam bahkan komunikasi ketika kita berusaha

Hubungan antara keadilan dan hukum positif menjadi perhatian yang besar para filsuf dari masa ke masa. Tokoh Madzab hukum alam/klasik, diantaranya seperti Plato, Aristoteles, dan Thomas Aquinasyang meletakkan dasar bagi keadilan. Plato melukiskan sebuah model negara yang adil dimana tiap-tiap golongan mempunyai tempat alamiahnya sehingga timbul keadilan. Filsuf ini mempertimbangkan adanya aturan hukum yang adil untuk mencapai tujuan hukum dengan tetap taat pada hal-hal yang menjadi keharusan alamiah (nomos). Bagi Plato, keadilan adalah pencerminan dari keharmonisan antara masyarakat di satu pihak dan individu di pihak lainnya (Zainuddin Ali 2006, 50).

Pemikiran Aristoteles yang merupakan murid plato semakin memperkaya ajaran tentang keadilan pada masa itu. Aristoteles menyumbang pemikiran penting terhadap perkembangan teori 
hukum diantaranya:

1. Formulasinya tentang problem esensial dari keadilan;

2. Formulasinya tentang perbedaan antara keadilan yang abstrak dengan equity;

3. Uraiannya tentang perbedaan keadilan hukum dan keadilan alamiah (seperti hukum positif dan hukum alam).

Aristoteles membuat perbedaan antara keadilan distributif, komutatif, dan keadilan remedial sebagaimana berikut ini:

1. Keadilan distributif adalah keadilan yang memberikan kepada setiap orang berdasarkan profesinya atau jasanya. Keadilan ini menghendaki agar orang-orang yang mempunyai kedudukan yang sama memperoleh perlakuan yang sama di hadapan hukum;

2. Keadilan komutatif yaitu keadilan yang memberikan hak kepada seseorang berdasarkan statusnya sebagai manusia;

3. Keadilan remedial, yaitu menetapkan kriteria dalam melaksanakan hukum sehari-hari harus mempunyai standar umum untuk memulihkan akibat tindakan yang dilakukan orang dalam hubungannya satu sama lain. Standar diterapkan tanpa membeda-bedakan orang.

Menurut Inge Dwisvimar, Aristoteles setidaknya menyumbangkan 4 kontribusi bagi filsafat hukum: Pertama, formulasinya terhadap keadilan yang memisahkan dalam 2 jenis kriteria besar yakni keadilan distributif dan korektif/remedial. Kedua, keadilan korektif/remedial menjadi dasar ukuran teknis dari prinsip-prinsip yang mengatur penerapan hukum. Aturan tentang hubungan hukum harus didasarkan pada standar umum untuk memperbaiki akibat dari tindakan tanpa memperhatikan pelakunya, dan tujuan dari perilaku dan objek tersebut harus diukur melalui ukuran objektif. Ketiga, pembedaan antara keadilan menurut hukum positif dan keadilan menurut alam. Keadilan menurut hukum positif mendapat legitimasi dari kekuasaan yang ada. Sedangkan keadilan menurut hukum alam mendapat legitimasi dari sifat dasar manusia yang tidak dibatasi ruang dan waktu. Keempat, pembedaanya terhadap keadilan abstrak dan kepatutan (Inge Dwisvimiar 2011,522).

Hukum cenderung menggunakan kekerasan dalam penerapannya. Kepatutan menjadi dasar mengurangi kekerasan atas dasar hak individu sekaligus bertujuan memberikan kemanfaatan.

Thomas Aquinas adalah murid Aristoteles yang mendasarkan teorinya tentang hukum dalam konteks moral agama kristen. Hukum diperlukan untuk menegakkan kehidupan moral di dunia. Tata hukum harus dibangun dalam struktur yang berpuncak pada kehendak Tuhan. Sehingga konfigurasi tata hukum dimulai dari (i) lex aeterna (hukum dan kehendak Tuhan), (ii) Lex Naturalis (prinsip umum/hukum alam), (iii) lex devina (hukum Tuhan dalam kitab suci), (iv) lex humane (hukum buatan manusia yang sesuai dengan hukum alam) (Bernard L Tanya 2010, 59-60). Thomas membedakan hukum yang berasal dari wahyu dan buatan manusia. Dimana hukum yang baik harus didasarkan pada akal yang mencerahkan, bukan kehendakyang bersifat naluriah. Ketika tata hukum yang dibuat manusia (ius positivum humanum berseberangan dengan prinsip ius naturale, maka hukum yang pertama harus dikalahkan. Lebih lanjut, Thomas Aquinas membagi keadilan dalam 3 hal yaitu (i) iustitia distributiva (keadilan distributif) yang menunjuk pada prinsip sama rata dan menunjuk kesederajatan geometris, (ii) iustitia commutativa (keadilan komutatif/tukar menukar) menunjuk pada keadilan berprinsip aritmetis yaitu penyesuaian yang harus dilakukan jika terjadi perbuatanyang tidak sesuai dengan hukum, (iii) iustitis legalis (keadilan hukum) yang menunjuk pada ketaatan akan hukum.

Pada abad modern terdapat filsuf yang mengembangkan konsep keadilan secara baik yaitu John Rawls. Rawls berpendapat bahwa keadilan hanya dapat ditegakkan jika negara melaksanakan asas keadilan berupa kebebasan setiap 
orang memiliki hak yang sama untuk mendapat kebebasan dasar (basic liberties) dan perbedaan sosial ekonomi hendaknya diatur sedemikian rupa sehingga memberi manfaat bagi mereka yang kurang beruntung. Rawl dalam bukunya a theory of justice berusaha menyajikan konsep keadilanyang menggeneralisasikan dan mengangkat teori kontrak sosial yang diajarkan Locke, Rousseau, dan Kant ke tingkat yang lebih tinggi. Pandangan tentang keadilan sebagai fairness didasarkan atas 2 prinsipyakni equal right dan economic equality (John Rawls 2011, 72). Pertama, semua orang mempunyai hak yang sama atas kebebasan dasar yang paling luas, seluas kebebasan yang sama bagi semua orang. Kedua, ketimpangan sosial dan ekonomi mesti diatur sedemikian rupa sehingga (a) dapat diharapkan memberikan keuntungan semua orang, dan (b) semua posisi dan jabatan terbuka bagi semua orang.

Pada demokrasi, secara epistimologi disyaratkan adanya partisipasi aktif dari masyarakat maka senada dengan hal itu keadilan juga membutuhkan serangkaian upaya untuk memperolehnya. Salah satu diantaranya adalah instrumen hukum yang progresif. Cita hukum ideal menurut Gustav Radburg meliputi, keadilan, kepastian, dan kemanfaatan. Ketiganya hadir saling melengkapi namun tidak jarang juga malah hilang di tataran realitas. Sebagai sebuah cita hukum, esensi keadilan dalam hal ini lebih tinggi dan mendasar tingkatannya. Sebuah cita hukum identik dengan harapan ideal yang cenderung bersifat abstrak dan belum dalam tataran realitas. Namun hal ini penting sebagai landasan filosof is negara dalam rangka menyusun produk hukum yang baik serta sesuai dengan kebutuhan. Proses mengartikulasikan tataran filosofis pada ranah realitas ini kemudian menjadi pekerjaan yang tidak mudah bagi pemerintah khususnya lembaga legislatif dan eksekutif. Cara mendaratkan harapan pada kenyataan memerlukan sebuah sinergi yang utuh antara unsur-unsur hukum. Lawrence M. Friedman mengemukakan komponen-komponen yang terkandung di dalam hukum yaitu struktur, substansi, dan kultural. Struktur adalah kelembagaan yang diciptakan oleh sistem hukum, komponen ini memungkinkan pemberian pelayanan dan penggarapan hukum secara teratur. Substansi terdiri dari norma hukum, baik peraturan, keputusan, dan sebagainya yang digunakan. Sedangkan kultural terdiri atas ide, sikap, harapan, dan pendapat tentang hukum. kultural ini dibedakan antara internal legal culture dan external legal culture (Esmi Warrasih 2005, 81-82). Komponen-komponen tersebut digunakan sebagai cara untuk meletakkan tujuan keadilan dalam hukum yang progresif ini. Pertama, struktur hukum melalui lembaga yang diberikan otoritas harus ada sebagai prasyarat pelaksanaan kegiatan operasional pertanahan. Lembaga ini kita kenal dengan nama Kementerian Agraria dan Tata Ruang/Badan Pertanahan Nasional yang tersebar hingga ke tingkat kabupaten. Lembaga ini secara rutin melaksanakan tugas administrasi pertanahan meskipun tuntutan peran mengharuskannya untuk berbuat lebih dari sekedar administratif. Kita sempat mendengar wacana tentang pembentukan pengadilan pertanahan dalam Rancangan Undang-undang (RUU) pertanahan. Hal ini akan semakin memperkuat kelembagaan pertanahan dalam memberikan pelayanan dan pencapaian tujuan keadilan. Kedua, substansi, substansi hukum agraria sangatlah luas. Sebagaimana pendapat Boedi Harsono bahwa kelompok hukum agraria meliputi hukum tanah, hukum air, hukum pertambangan, hukum perikanan, dan hukum penguasaan atas tenaga dan unsur-unsur dalam ruang angkasa (Boedi Harsono 2003, 8). Mengingat begitu luasnya masalah agraria, maka sudah bisa dipastikan diperlukan sinergi dan koordinasi antar sektoryang ada. Realitas saat ini menunjukkan bahwa berbagai ketentuan hukum tersebut berpotensi tidak sinkron dan cenderung saling meniadakan satu dengan yang lain. Sehingga belum nampak adanya kesa- 
tuan tunggal pengelolaan agraria. Ketiga, kultural hukum yang terdiri dari internal legal culture dan external legal culture. Watak birokrasi Indonesia termasuk pertanahan masih menunjukkan keinginan untuk dilayani dan bukan melayani. Aparatur negara hanya bertugas sebagai corong undang-undang dan berusaha menjamin terciptanya ketertiban dan keteraturan dalam masyarakat. Sementara itu masyarakat sudah mulai menunjukkan kesadaran hukum yang lebih tinggi. Meskipun nilai-nilai kekeluargaan masih tampak, namun kecenderungan untuk reaktif juga terlihat dalam menyikapi berbagai permasalahan yang ada.

Mengkonfirmasi progresivitas hukum agraria Indonesia dalam ukuran keadilannya, maka perlu dilihat berdasar beberapa teori tentang tujuan hukum. Meminjam ajaran teori etis tentang tujuan hukum, hukum semata-mata bertujuan untuk menemukan keadilan. Perhatian pokok teori ini terbagi atas 2 hal. Pertama, menyangkut hakikat keadilan yang terletak pada penilaian terhadap suatu perlakuan atau tindakan dimana hakikat keadilan hendaknya dilihat dari dua pihak. Kedua, menyangkut isi atau norma untuk berbuat secara konkrit dalam keadaan tertentu. Hal ini sangat sulit pada pembatasan terhadap isi keadilan sehingga ada kecenderungan memberikan penilaian terhadap rasa keadilan hanya menurut pihak yang menerima perlakuan saja (Esmi Warrasih 2005, 24). Jika dikaitkan dengan ajaran teori ini, kita dapat mengkonfirmasinya pada realitas hukum agraria yang ada di Indonesia. Pada masa awal pembentukan hukum tanah nasional khususnya UUPA di tahun 1960, kita dapat melihat bahwa pertimbangan tujuan keadilan ini sangat menonjol. Pemerintah kala itu berusaha memberikan keadilan melalui keberpihakan perangkat hukum dalam bidang agraria kepada masyarakat, sebut saja beberapa ketentuan tentang penghapusan tanah partikelir, pembatasan luas tanah pertanian, larangan tanah absentee, maupun juga paket kebijakan land reform dengan redistribusi tanahnya.
Kesemuanya bertujuan untuk merombak struktur penguasaan tanah agar tidak terkonsentrasi pada golongan tertentu saja namun dapat merata memberikan kemakmuran pada rakyat. Pemberian asset reform dan acces reform menjadi ujung tombak pemerintah dalam mewujudkan keadilan agraria. Namun seiring perkembangan jaman, regulasi tentang keagrariaan dilihat tidak lagi mampu mengikuti dinamika perkembangan jaman dan tuntutan globalisasi. Beberapa ketentuan hukum yang lahir pada masa orde baru yang dikenal dengan 3 paket UU di tahun 1967 menandai perubahan mendasar dalam pengelolaan agraria diantaranya:

1. UU No. 1 tahun 1967 tentang Penanaman Modal Asing

2. UU No. 5 tahun 1967 tentang Ketentuan-ketentuan Pokok Kehutanan, yang kemudian diganti dengan UU No. 41 Tahun 1999.

3. UU No. 11 tahun 1967 tentang Ketentuanketentuan Pokok Pertambangan, dan UU No. 4 Tahun 2009 tentang Pertambangan Mineral Batubara.

Penerapan ketiga undang-undang tersebut dimaksudkan untuk mendorong kinerja ekonomi yang lebih kuat melalui pembukaan investasi asing ke Indonesia dengan penyediaan iklim usaha yang mendukung. Sehingga berbagai korporasi dan investasi asing masuk dan "berbagi" sumber daya alam yang melimpah. Hukum yang ada diarahkan untuk menjamin adanya ketertiban dan keteraturan dalam masyarakat. Hukum juga ditujukan untuk mencapai keadilan secara berbeda-beda baik menurut isi dan ukurannya serta menurut masyarakat dan zamannya (Esmi Warrasih 2005, 25). Hal ini sebagaimana ajaran teori campuran tentang tujuan hukum. Bahkan jika kita melihat kondisi pada saat ini, hukum agraria kita masih mempertahankan corak yang demikian ini. Harapan akan keadilan menjadi jauh panggang dari api, karena negara dengan kewenangannya mempertahankan keteraturan dan ketertiban sebagai yang utama 
daripada keadilan bagi masyarakat umum.

Tri Chandra Aprianto menyebutkan bahwa sejak dipilihnya pembangunan ekonomi yang berbasis free fight liberalism (1967) model mengatasi ketidakadilan agraria politik orde baru memilih pendekatan jalan pintas (by pass approach) (Tri Chandra A 2014, 356). Pendekatan ini secara tegas menyebutkan bahwa problem mendasar masyarakat Indonesia (khususnya kaum tani) bukanlah penataan ulang sumber agraria yang lebih adil namun masalah pangan, lapangan kerja, dan kesempatan kerja (Arbi Sanit 1980, 37-38). Fokus pemerintah yang melupakan urgensi tanah sebagai basis ekonomi menempatkan tanah kemudian menjadi komoditas dan faktor ekonomi dalam rangka pemenuhan kebutuhan pangan dan lapangan pekerjaan. Hal ini sekaligus mengamini proses industrialisasi dan kapitalismeyang luar biasa ke Indonesia pada periode tersebut.

Pada masa sekarang ini tidak banyak terjadi perubahan yang signifikan. Harapan akan keadilan melalui pengaturan hukum agraria yang progresif dan responsif atas harapan masyarakat masih belum terlaksana. Pemerintah masih berfokus pada kemajuan investasi dan korporasi serta kurang memperhatikan kebutuhan masyarakat. Kesadaran akan pentingnya keadilan di bidang hukum khususnya agraria dan ekonomi mulai dibangun pasca reformasi melalui reforma agraria. Namun Konsorsium Pembaharuan Agraria (KPA) mencatat indikasi kemiskinan dan hilangnya kedaulatan atas sumber daya agraria dan potensi kerawanan sosial di masa depan yang lebih besar. Konflik agraria sejumlah 1.379 meletus dan membawa korban jiwa. Sepanjang tahun 2013 dari sisi korban terdapat 139.874 kepala keluarga menjadi korban konflik, 22 tewas, 239 ditangkap, 130 dianiaya, dan 30 orang ditembak mati (Iwan Nurdin 2014). Hal ini menunjukkan bahwa perangkat hukum masih digunakan pemerintah sebagai upaya yang represif untuk melegalkan segala kebijakannya. Hukum seolah berdiri dalam ruang yang bebas nilai dan bebas kepentingan termasuk tidak mengindahkan harapan masyarakat sebagai ruang bekerjanya hukum.

Perjuangan masyarakat untuk memperoleh keadilan dalam penegakan untuk mendorong munculnya berbagai aksi dan gerakan baik secara diplomatis maupun radikal. Penggunaan tatanan hukum lokal yang identik dengan adat serta hukum nasional yang identik bersifat represif seringkali memunculkan gesekan yang seringkali mengakibatkan korban. Proklamasi kemerdekaan hendaknya kembali mengingatkan kita tentang revolusi nasional termasuk penataan hukum agraria yang berkonsepsi nasional. Pancasila haruslah menjadi panduan utama bagi negara dalam melaksanakan kebijakan-kebijakannya. Pancasila tidak saja berfungsi sebagai dasar negara tetapi juga menjadi rechtsidee, yaitu tuntunan menuju cita-cita moral bangsa yang merujuk pada perasaan keadilan masyarakat (Tri Chandra A 2014, 356). Masyarakat dengan tatanan hukum lokalnya baik berupa kearifan lokal maupun hukum adat merupakan kekayaan nasional yang penuh dengan nilai dan filosofi kebersamaan. Alternatif-alternatif pilihan hukum yang dipromosikan oleh masyarakat, menunjukkan kedudukannya sebagai pelengkap dalam sistem hukum nasional. Sehingga keragaman tatanan hukum yang ada serta perubahan konfigurasi politik nasional turut menggambarkan dinamika hukum agraria nasional kesemuanya berupaya mengarah pada pencapaian keadilan.

\section{Pluralisme Hukum Agraria sebagai Sintesis Keadilan Hukum}

Pembangunan sistem hukum nasional di Indonesia merupakan sebuah pekerjaan yang berat di tengah keragaman budaya serta karakteristik masyarakat. Variabel hukum dan masyarakat memiliki keterikatan yang tidak dapat dipisahkan. Hukum dibentuk berfungsi untuk mengatur dan menciptakan ketertiban dalam masyarakat, demikian pula sebaliknya bahwa masyarakat 
memilih dan melegitimasi hukum yang sesuai dengan cita hukumnya untuk dapat digunakan mengatur pola kehidupannya. Pola hubungan timbal balik dan ketergantungan ini pada satu sisi dapat selaras dengan maksud pemerintahan yang berdaulat yang terwujud melalui hukum formal negara. Namun pada kondisi yang lain, hukum nasional dianggap kurang sesuai oleh masyarakat sehingga menggunakan pilihan hukum lain. Situasi dimana terdapat suatu bidang kehidupan atau urusan yang sama dapat berlaku berbagai norma dari hukum yang berbeda diartikan sebagai kondisi pluralisme hukum (Myrna A, Safitri 2011, 1). Norma yang berlaku dapat berasal dari hukum adat, hukum perdata (barat), hukum agama, dan sistem hukum lainnya.

Kondisi pluralisme hukum dalam bidang keagrariaan di Indonesia menunjukkan kondisi yang menurut Sumardjono adalah weak legal pluralism/ state-law pluralism (Maria SW Sumardjono 2017, 4). Diskursus tentang interaksi hukum nasional dan hukum adat dalam bidang pertanahan tidak harus ditempatkan dalam kondisi kompetisi namun justru saling melengkapi/ komplementer. Secara sifatnya, hukum nasional/ formal cenderung bersifat statis dan stabil dalam arti untuk mempertahankan norma dan kondisi ketertiban dalam masyarakat sehingga cenderung kurang dinamis. Sementara itu nilai hukum adat yang hidup dalam masyarakat cenderung lebih dinamis dan lokal karena berada dalam lingkungan masyarakat sebagai wilayah operasionalnya. Oleh karenanya kondisi komplementer ini juga dapat dipahami mengingat kelemahan kedua karakteristik sistem hukum tersebut yaitu bahwa hukum nasional memiliki keunggulan adanya kepastian hukum sedangkan hukum adat dinilai lebih memberikan rasa keadilan bagi masyarakat.

Pemahaman atas keragaman tatanan sistem hukum yang berbeda-beda berimplikasi pada pilihan hukum oleh masyarakat. Menghadapi perkembangan dan globalisasi dalam bidang ekonomi, sektor agraria khususnya pertanahan juga mengalami desakan khususnya dalam tatanan lokal. Tatanan struktur global secara perlahan diwakili oleh tatanan hukum nasional yang mendapatkan tekanan untuk mengakomodir kemajuan global. Sementara struktur lokal dapat kita temui dalam pengaturan hukum adat maupun kebiasaan dan kearifan lokal yang dikembangkan oleh masyarakat. Sebagai contoh kebijakan negara dalam sertipikasi tanah masyarakat hukumadat. Pada satu sisi sertipikasi menjadi alat global dan negara untuk memenuhi tuntutan dunia dalam rangka membuka kran investasi dan pengakuan atas pemilikan pribadi. Namun disisi lain, sertipikasi juga mendorong individualisasi tanah dan kepastian hukum melalui bukti kepemilikan tanah. Kesadaran akan kebutuhan pengakuan penguasaan tanah mendorong masyarakat adat ikut serta dalam program ini. Sebagai tahapan awalnya, pengakuan subyek hak yakni masyarakat adat menjadi prasyarat yang mendorong masyarakat adat untuk memenuhi kriteria yang ditentukan negara. Masyarakat hukum adat menurut ahli kolonial dikategorikan sebagai persekutuan hukum. Persekutuan hukum menurut Ter Haar harus memenuhi kriteria (Andiko 2011, 60):

1. Merupakan kesatuan manusia yang teratur

2. Menetap di suatu daerah tertentu

3. Mempunyai penguasa

4. Mempunyai kekayaan baik yang berwujud maupun tidak berwujud.

Penetapan subyek hukum sebagai masyarakat hukum adat menurut ketentuan hukum nasional membutuhkan pengakuan baik dalam bentuk peraturan daerah maupun keputusan kepala daerah/bupati/walikota. Meskipun demikian, ditegaskan bahwa penetapan melalui keputusan ini hendaklah bersifat deklaratoir semata (Maria SW Sumardjono 2016, 6).

Terdapat proses penundukan diri tatanan lokal terhadap tuntutan global. Kekuatan global dan tatanan lokal memiliki titik singgung yaitu 
keduanya berusaha mencapai cita-cita kemakmuran materiil dalam masyarakatnya (Ade Saptomo 2010, 32). Hal ini artinya, kondisi lingkungan masyarakat sebagai wilayah bekerjanya hukum menunjukkan pluralisme dan semakin dinamis termasuk juga karakteristik masyarakat dengan keragaman suku, agama, budaya, dan lingkungan geografisnya.

Pluralisme hukum bagi gerakan sosial penting karena keadilan dapat ditemukan di berbagai hukum (Myrna A, Safitri 2011, 13). Bagi sebagian kalangan khususnya yang menentang faham positivisme hukum, apabila keadilan menjadi pokok utamanya maka perlukah hukum negara hadir atau tidak bukan menjadi hal yang secara $a$ priori bisa ditetapkan. Hal ini sekaligus mengesahkan keberadaan pluralisme hukum sebagai kondisi yang melahirkan banyaknya peluang dan kemungkinan untuk melakukan seleksi atas sistem hukum yang paling banyak memberikan rasa keadilan bagi masyarakat. Meskipun kemudian hal yang menjadi kelemahan utama dalam pluralisme hukum adalah ketiadaan kepastian hukum. Namun seperti pepatah lama yang mempertanyakan mana yang lebih dulu antara ayam dan telur, maka banyak kalangan yang menyatakan apalah arti kepastian hukum kalau ternyata masyarakat masih mencari norma hukum baru yang memberi keadilan. Maka sesuatu yang pasti menjadi hal yang tidak pasti secara hakiki.

Pluralisme hukum memberikan peluang dan kemungkinan bagi masyarakat untuk memilih dan menggunakan hukum agraria yang paling sesuai dengan memberikan keadilan. Contohyang paling sering muncul adalah pilihan masyarakat dalam menggunakan hukum waris dalam keluarga. Para pihak dapat menggunakan hukum waris menurut hukum barat, hukum adat, maupun menurut hukum agama yaitu Islam. Terhadap pilihan hukum ini, negara mengakui dan memberikan perlindungan terhadapnya. Contoh lain, adalah dalam model pengelolaaan tanah adat pada masyarakat
Bali, dikenalnya lembaga desa pakraman dan desa dinasyang memiliki yurisdiksi kewenangan masingmasing. Negara melegitimasi kewenangan yang ada dan mengakomodir dalam pengaturan pada tataran hukum nasional melalui penetapan peraturan daerahnya. Kedua contoh tersebut menjadi gambaran bahwa hukum adat sebagai pelengkap/komplemen hukum nasional memungkinkan bagi negara untuk melakukan penyesuaian dan perubahan hukum nasional mengikuti perkembangan zaman dan masyarakat dengan mengakomodir hukum adat/hukum masyarakatyang ada. Fleksibilitas dan keluwesan hukum ini dimungkinkan dengan kondisi hukum yang plural. Patrick McAusland dalam Warman menyebutkan hubungan hukum adat dan hukum nasional melalui beberapa tahapan diantaranya acquisition, destruction, reconstruction, substitution, dan integration (Kurnia Warman 2009, 90-92). Pengaturan konversi UUPA yang memberikan pengaturan tentang hak-hak atas tanah masyarakat hukum adat menunjukkan fase substitution. Perlahan namun pasti, karakteristik pluralisme hukum yang mempromosikan hukum masyarakat ini semakin menguat, namun yang perlu diperhatikan bahwa pluralisme hukum harus bersifat positif dan ditujukan untuk pembangunan hukum nasional. Sehingga di masa mendatang, hukum adat/hukum masyarakat benar-benar memiliki kedudukan dan peran dalam memberikan kontribusi merespons tuntutan zaman dengan tetap berlandaskan pada nilai-nilai kearifan lokal dan filosof is kepribadian bangsa yang komunalistikdan religius, serta mengutamakan nilai-nilai pancasila.

\section{E. Penutup}

Kehidupan manusia mulai dari yang primitif sampai dengan modern bahkan post modern senantiasa ditata dengan ketentuan hukum. Hukum tidak hanya dipahami sebagai pembentuk ketertiban dan keteraturan namun lebih dari ini hukum harus mampu memberikan keadilan, kepastian, dan kemanfaatan kepada manusia. Sebagai sebuah 
produk akal dan qalbu, hukum senantiasa diharapkan dinamis mengikuti perkembangan dan tuntutan jaman. Sehingga harapannya dengan sifatnya yang lentur dan dinamis ini akan mampu memenuhi cita-cita hukum masyarakat akan keadilan yang substantif.

Hukum agraria di Indonesia di bentuk dengan tekad untuk membangun hukum agraria nasional yang sesuai dengan karakteristik bangsa Indonesia yang komunalistik religius. Hukum dibangun pada masa transisi kemerdekaan untuk mengakhiri sistem hukum Barat yang individual liberal dan eksploitatif menuju hukum yang adil, berpihak pada masyarakat, dan berdasarkan Pancasila sebagai filosofi bangsa. Kondisi pluralisme hukum menggambarkan begitu majemuk dan heterogennya masyarakat serta kondisi kehidupannya yang berkembang sesuai tuntutan global. Pluralisme hukum menjadi kondisi yang memungkinkan bagi masyarakat untuk menampilkan pilihan-pilihan hukum yang sesuai dengan cita keadilan dan kemanfaatan bagi masyarakat. Di bidang agraria, kondisi hukumnya menunjukkan gejala awal legal pluralism di mana hukum negara masih dominan serta hukum adat/kebiasaan berperan sebagai komplemen/pelengkap. Hukum progresif sebagai gambaran norma hukum yang sesuai dengan tuntutan serta kondisi zaman menjadi potensi yang mampu dilahirkan dalam kondisi hukum yang plural. Meskipun miskin akan kepastian hukum, namun kaya akan dimensi keadilan yang sejatinya menjadi tujuan penegakan hukum.

\section{Daftar Pustaka}

Ali, Z 2006, Filsafat Hukum, Sinar Grafika, Jakarta. Andiko 2011, Upaya Tiada Henti Mempromosikan Pluralism Dalam Hukum Agraria Di Indonesia Dalam "Untuk Apa Pluralisme Hukum? Regulasi, Negosiasi, Dan Perlawanan Dalam Konflik Agraria Di Indonesia,"Myrna A, Savitri (ed), Ephistema Institute, HuMA, Forest People Programme, Jakarta.
Aprianto, TC 2014, Reforma Agraria: Momentum Keadilan dan Kesejahteraan, Jurnal Bhumi, No, 39 Tahun 13, April 2014.

Arizona, Y 2014, Konstitusionalisme Agraria, STPN Press, Yogyakarta.

Dwisvimiar, I, "Keadilan Dalam Perspektif Filsafat Ilmu Hukum”, Jurnal Dinamika Hukum, Vol, 11 No, 3 September 2011.

Harsono, B 2003, Hukum Agraria Indonesia: Sejarah Pembentukan Undang-undang Pokok Agraria, Isi dan Pelaksanaannya, Jilid 1 Hukum Tanah Nasional, Djambatan, Jakarta.

Hatta, M 2005, Hukum Tanah Nasional Dalam Perspektif Negara Kesatuan, Media Abadi, Yogyakarta.

Held, D 2004, Demokrasi dan Tatanan Global; Dari Negara Modern Hingga Pemerintahan Kosmopolitan, Pustaka Pelajar, Yogyakarta.

Indarti, E, "Demokrasi dan kekerasan: Sebuah Tinjauan Filsafat Hukum”, Aequitas Juris, Jurnal Fakultas Hukum Universitas Katholik Widya Mandira Kupang, Vol, 2 (1), 2008.

Mahfud, M 2011, Politik Hukum di Indonesia, Rajawali Pers, Jakarta.

Nurdin, I 2014, KPA Desak Jokowi-JK Prioritaskan Reforma Agraria dalam http://www.kpa.or.id/ news/blog/kpa-desak-jokowi-jk-prioritaskanreforma-agraria/, Diakses tanggal 9 Oktober 2015 Pukul 05.19 WIB.

Rawls, J 2011, A Theory of Justice, Teori Keadilan: Dasar-dasar Filsafat PolitikuntukMewujudkan Kesejahteraan Sosial dalam Negara, Pustaka Pelajar, Yogyakarta.

Safitri, MA 2011, Bersikap Kritis Terhadap Pluralisme Hukum dalam "Untuk Apa Pluralisme Hukum? Regulasi, Negosiasi, dan Perlawanan Dalam Konflik Agraria di Indonesia," Myrna A, Savitri (ed), Ephistema Institute, HuMA, Forest People Programme, Jakarta.

Salim HS dan Erlies SN 2014, Penerapan Hukum Pada Penelitian Disertasi dan Tesis, Buku Kedua, Raja Grafindo, Jakarta.

Sanit, A, Kegiatan PKI di Kalangan Petani di Jawa Tengah dan Jawa Timur Pada Tahun 50-an, Jurnal Persepsi Untuk Mengamankan Pancasila, Tahun II No. I, 1980. 
Saptomo, A 2010, Hukum dan Kearifan Lokal, Revitalisasi Hukum Adat Nusantara, Grasindo, Jakarta.

Sudjito 2013, Hukum Dalam Pelangi Kehidupan: Hukum ProgresifUntuk Mewujudkan Keadilan Substantif Dalam Bingkai Nilai-Nilai Pancasila,Tugu Yogya Pustaka, Yogyakarta. , 2015, Material Teaching Filsafat Ilmu Hukum, FH UGM, Yogyakarta.

Sumardjono, MSW 2016, Sekali Lagi tentang Hak Komunal, Kompas edisi 19 Juli 2016. , 2017, Pluralisme Hukum Dalam Pengaturan Sumberdaya Alam di Indonesia, Adaptasi, Harmonisasi dan Agenda ke Depan, Orasi Ilmiah disampaikan dalam Rapat Senat Terbuka dalam Rangka Dies Natalis ke-71 Fakultas Hukum Universitas Gadjah Mada, Yogyakarta.

Susanto, AF 2010, "Keraguan dan ketidakadilan Hukum (Sebuah Pembacaan Dekonstruktif)", Jurnal Keadilan Sosial, Edisi 1 Tahun 2010.
Tanya, BL, Yoan N Simanjuntak, dan Markus YH 2010, Teori Hukum: Strategi Tertib Manusia Lintas Ruang dan Generasi, Genta Publishing, Yogyakarta.

Warman, K 2009, Pengaturan Sumberdaya Agrarian Pada Era Desentralisasi Pemerintahan Di Sumatera Barat (Interaksi Hukum Adat Dan Hukum Negara Dalam Perspektif Keanekaragaman Dalam Kesatuan Hukum), Program Pascasarjana Fakultas Hukum Universitas Gadjah Mada, Yogyakarta.

Warrasih, E 2005, Pranata Hukum Sebuah Telaah Sosiologis, Suryandaru Utama, Semarang.

Winarno, B 2007, Kebijakan Publik: Teori dan Proses, Media Pressindo, Yogyakarta.

Yani, A 2013, Pembentukan Peraturan Perundangundangan Yang Responsif: Catatan Atas UUNo, 12 Tahun 2011 tentang Pembentukan Peraturan Perundang-undangan, Konstitusi Press, Jakarta. 